NUSANTARA : Jurnal IImu Pengetahuan Sosial - Vol. 6 No 1 (2019) ( Januari - Juni )

issn online : $2550-0813$ issn cetak : 2541-657X

http://jurnal.um-tapsel.ac.id/index.php/nusantara

\title{
PENGARUH SOSIAL EKONOMI TERHADAP POLA PENURUNAN PENGANGGURAN TERBUKA DI PROVINSI SUMATERA UTARA TAHUN 2003-2017
}

\author{
Francisca WAWSari ${ }^{1}$, Rita Herawaty Bangun ${ }^{2}$ \\ ${ }^{1}$ Fungsional Statistisi Muda BPS Provinsi Sumatera Utara \\ ${ }^{2}$ Fungsional Statistisi Madya BPS Provinsi Sumatera Utara \\ Jalan Asrama No. 179 Medan, Sumatera Utara, 20123 \\ Email: fwenny@bps.go.id
}

\begin{abstract}
Abstrak
Penelitian ini bertujuan untuk menganalisis dan mengidentifikasipengaruh sosial ekonomi terhadap tingkat pengangguran terbuka di Provinsi Sumatera Utara. Penelitian ini menggunakan data runtut waktu selama tahun 2002-2017 yang terdiri dari data inflasi, persentase penduduk miskin, upah minimum regional dan rata-rata lama sekolah,Metode analisis yang digunakan dalam penelitian ini adalah analisis regresi linier berganda. Hasil penelitian menunjukkan bahwa variabel inflasi, persentase penduduk miskin, upah minimum regional dan rata-rata lama sekolah secara simultan berpengaruh secara nyata terhadap tingkat pengangguran terbuka namun secara partial hanya variabel rata-rata lama sekolah yang berpengaruh terhadap tingkat pengangguran terbuka di Provinsi Sumatera Utara.
\end{abstract}

Kata kunci: Tingkat pengangguran terbuka, indikator sosial ekonomi

\section{PENDAHULUAN}

Sebagai negara berkembang, Indonesia masih mengalami proses pembangunan ekonomi yang bertujuan untuk mencapai kesejahteraan masyarakat. Salah satu cara mewujudkannya adalah dengan menyediakan kesempatan kerja dan terciptanya pemerataan pendapatan. Masih adanya kesenjangan antara jumlah lapangan kerja yang tersedia dengan jumlah angkatan kerja memicu terciptanya pengangguran yang nantinya juga akan berdampak pada kehidupan sosial lainnya seperti meningkatnya kriminalitas. Pengangguran merupakan salah satu masalah di bidang ekonomi yang dihadapi oleh Indonesiatermasuk di Provinsi Sumatera Utara sebagai provinsi dengan jumlah penduduk terbesar keempat di Indonesia(BPS, 2018b).

Pengangguran merupakan penduduk yang tidak bekerja tetapi sedang mencari pekerjaan atau sedang mempersiapkan suatu usaha baru atau penduduk yang tidak mencari pekerjaan karena sudah diterima bekerja tetapi belum mulai bekerja(BPS, 2018a). Pengangguran dapat juga diartikan sebagai seseorang yang tergolong dalam angkatan kerja dan secara aktif mencari pekerjaan pada suatu tingkat upah tertentu (Muslim, 2014).

Penelitian tentang pengangguran sudah banyak dilakukan, diantaranya yang dilakukan oleh Susanto, et all., (2017) yang 
NUSANTARA : Jurnal Ilmu Pengetahuan Sosial - Vol. 6 No 1 (2019) ( Januari - Juni )

issn online : $2550-0813$ issn cetak : $2541-657 \mathrm{X}$

http://jurnal.um-tapsel.ac.id/index.php/nusantara

meneliti pengaruh inflsi dan pendidikan terhadap pengangguran dan kemiskinan. Muslim (2014) juga meneliti tentang pengangguran terbuka dan determinannya. Penelitian tentang determinan tingkat pengangguran terbuka di Provinsi Banten juga dilakukan oleh Sidania et all (2017).

Pengangguran merupakan masalah yang kompleks dan penting untuk dibahas karena berkaitan dengan indikator sosial ekonomi dalam proses pembangunan untuk mewujudkan kesejahteraan masyarakat. Beberapa indikator ekonomi yang berhubungan dengan tingkat pengangguran adalah inflasi dan upah minimum. Inflasi dan upah minimum berhubungan dengan pengangguran. Tingginya inflasi akan mengakibatkan harga barang domestik lebih mahal dari barang impor sehingga mempengaruhi penurunan pada produksi barang dan jasa yang secara tidak langsung berkaitan dengan penambahan tingkat pengangguran (Susanto, et all., 2017). Upah juga mempengaruhi tingkat pengangguran secara langsung dan tidak langsung. Penetapan tingkat upah yang dilakukan pemerintah, serikat pekerja, dan kalangan pengusaha pada suatu negara akan memberikan pengaruh terhadap besarnya tingkat pengangguran. Jika semakin tinggi besaran upah yang ditetapkan maka hal tersebut akan berakibat pada penurunan jumlah orang yang bekerja pada negara tersebut. Sehingga semakin tinggi tingkat upah yang ditetapkan akan membawa pengaruh pada tingginya tingkat pengangguran yang akan terjadi(Suhendra \& Wicaksono, 2016). Tingkat pendidikan juga berpengaruh terhadap tingkat pengangguran. Semakin tingginya tamatan pendidikan seseorang maka semakin tinggi pula kemampuan kerja atau produktivitas seseorang dalam bekerja (Suhendra \& Wicaksono, 2016).

Berdasarkan uraian di atas maka perlu dilakukan penelitian untuk menganalisis dan mengidentifikasi pengaruh indicator sosial ekonomi terhadap tingkat pengangguran di Provinsi Sumatera Utara. Tujuan dari penelitian ini adalah untuk menganalisis dan mengidentifikasi indikatorsosial ekonomi terhadap tingkat pengangguran di Provinsi Sumatera Utara.

\section{METODE}

\section{Jenis Penelitian}

Penelitian ini adalah penelitian explanatory research, yaitu metode penelitian yang menjelaskan hubungan antara variabel-variabel bebas dan variabel terikat (Firdhania \& Muslihatinningsih, 2017).

\section{Sumber Data dan Variabel Penelitian}

Data yang digunakan dalam penelitian ini merupakan data sekunder yang bersumber dari Badan Pusat Statistik Provinsi Sumatera Utara. Data yang digunakan adalah data deret waktu selama kurun waktu tahun 2003-2017. Variabel-variabel yang digunakan dalam penelitian ini yaitu tingkat pengangguran terbukasebagai variabel terikat sedangkan variabel bebas meliputi variabel ekonomi yang terdiri dari data inflasi, persentase penduduk miskin, dan upah minimum regional sedangkan variabel pendidikan adalah data rata-rata lama sekolah.

\section{Metode Analisis Data Analisis Regresi Berganda}

Metode analisis yang digunakan dalam kajian ini adalah analisis data dengan banyak peubah (multivariate) yaitu analisis linier 
NUSANTARA : Jurnal Ilmu Pengetahuan Sosial - Vol. 6 No 1 (2019) ( Januari - Juni )

issn online : $2550-0813$ issn cetak : 2541-657X

http://jurnal.um-tapsel.ac.id/index.php/nusantara

regresi berganda. Analisis regresi linier berganda digunakan untuk melihat hubungan fungsional antara variabel prediktor dengan variabel kriteriumnya. Model persamaan regresi linier berganda dirumuskan sebagai berikut (Bangun, 2018):

$\hat{y}=\alpha_{0}+\alpha_{1} x_{1}+\ldots+\alpha_{k} x_{k}+\varepsilon$.(1)

dimana:

$\hat{\mathrm{y}} \quad=$ variabel tidak bebas

(dependent)

$\alpha_{0, \ldots, \alpha_{\mathrm{k}}}=$ koefisien regresi

$\mathrm{x}_{1}, \ldots \ldots, \mathrm{x}_{\mathrm{k}}=$ variabel bebas

(independent)

$\mathcal{E}=$ standard error

Koefisien Determinasi $\left(\mathbf{R}^{2}\right)$

Koefisien determinasi $\left(\mathrm{R}^{2}\right)$ digunakan sebagai informasi mengenai kecocokan suatu model. Nilai koefisien determinasi antara 0 sampai dengan 1. Dinamakan koefisien determinasi karena $\mathrm{R}^{2} \mathrm{x}$ $100 \%$ daripada variasi yang terjadi dalam variabel tak bebas $\mathrm{Y}$ dapat dijelaskan oleh variabel bebas $\mathrm{X}$ dengan adanya regresi linier $\mathrm{Y}$ atas $\mathrm{X}$. Besarnya harga koefisien determinasi adalah berkisar $0<\mathrm{R}^{2}<1$. Artinya jika $\mathrm{R}^{2}$ mendekati 1 maka dapat dikatakan pengaruh variabel bebas terhadap variabel terikat adalah besar. Berarti model yang digunakan baik untuk menjelaskan pengaruh variabel tersebut.

\section{Uji Asumsi Klasik}

1. Uji Normalitas

Uji ini merupakan pengujian terhadap normalitas kesalahan pengganggu/error yang digunakan untuk melihat apakah variabel bebas dan variabel terikat berdistribusi normal.

2. Uji Heteroskedastisitas

Heteroskedastisitas adalah

varian residual yang tidak sama pada semua pengamatan di dalam model regresi. Regresi yang baik seharusnya tidak terjadi heteroskedastisitas. Pengujian heterokesdasitas dapat dilakukan dengan Uji Glejser, Uji Park, Uji Spearman dan grafik.

3. Uji Multikolineritas

Menunjukkan adanya lebih dari satu hubungan linier yang sempurna. Koefisien-koefisien regresi biasanya diinterprentasikan sebagai ukuran perubahan variabel terikat jika salah satu variabel bebasnya naik sebesar satu unit dan seluruh variabel bebas lainnya dianggap tetap. Untuk mendeteksi adanya multikolinieritas adalah dengan menggunakan nilai Variance Inflation Factor (VIF). Jika VIF lebih kecil dari 10, maka dalam model tidak terdapat multikolinieritas.

4. Uji Autokorelasi

Konsekuensi adanya autokorelasi dalam suatu model regresi adalah varians sampel tidak dapat menggambarkan varians populasinya. Selain itu model regresi yang dihasilkan tidak dapat digunakan untuk menaksir nilai variabel independent tertentu (X). Untuk mendiagnosis adanya autokorelasi dalam suatu model regresi dilakukan pengujian terhadap nilai uji Durbin Watson (DW). Menentukan kriteria pengujian untuk autokorelasi positif:

$\mathrm{H}_{\mathrm{o}}$ : diterima jika $\mathrm{d}>\mathrm{d}_{\mathrm{L}}$ dan $\mathrm{H}_{1}$ ditolak jika $\mathrm{d}<\mathrm{d}_{\mathrm{u}}$

$\mathrm{H}_{\mathrm{o}}$ : diterima jika (4-d) $<\mathrm{d}_{\mathrm{u}}$ dan $\mathrm{H}_{1}$ ditolak jika $(4-d)<d_{L}$

\section{Uji Hipotesis}

a. Uji Hipotesis secara Simultan (Uji F)

Pengujian signifikansi terhadap model secara simultan (bersama-sama) dimaksudkan untuk melihat kemampuan seluruh variabel bebas mampu menjelaskan keragaman variabel tidak bebas. Kriteria pengujian adalah sebagai berikut: 
NUSANTARA : Jurnal Ilmu Pengetahuan Sosial - Vol. 6 No 1 (2019) ( Januari - Juni )

issn online : $2550-0813$ issn cetak : 2541-657X

http://jurnal.um-tapsel.ac.id/index.php/nusantara

$\mathrm{H}_{0} \quad$ : Tidak ada pengaruh inflasi, persentase penduduk miskin, upah minimum regional dan rata-rata lama sekolah terhadap tingkat pengangguran terbuka

$\mathrm{H}_{1} \quad$ : Ada pengaruh inflasi, persentase penduduk miskin, upah minimum regional dan rata-rata lama sekolah terhadap tingkat pengangguran terbuka

Kriteria pengujian sebagai berikut:

Jika F-hitung lebih besar dari nilai Ftabel berarti terima $\mathrm{H}_{1}$ tolak $\mathrm{H}_{\mathrm{o}}$

Kesimpulan: Variabel bebas secara simultan dapat menerangkan variabel tidak bebas, berarti model tersebut dapat digunakan

b. Uji Hipotesis secara Parsial (Uji t)

Uji ini dimaksudkan untuk menguji apakah suatu variabel bebas berpengaruh atau tidak secara nyata (signifikan) terhadap variabel tidak bebas. Kriteria pengujian sebagai berikut:

$\mathrm{H}_{0}$ : Tidak ada hubungan yang signifikan antara inflasi, persentase penduduk miskin, upah minimum regional dan rata-rata lama sekolah terhadap pengangguran terbuka

$\mathrm{H}_{1}$ : Ada hubungan yang signifikan antara inflasi, persentase penduduk miskin, upah minimum regional dan rata-rata lama sekolah terhadap tingkat pengangguran terbuka

Kriteria pengujian sebagai berikut:

Jika t-hitung lebih besar dari nilai ttabel berarti terima $\mathrm{H}_{1}$ tolak $\mathrm{H}_{\mathrm{o}}$

Kesimpulan: Ada variabel bebas yang berpengaruh nyata terhadap variabel tidak bebas

\section{HASIL DAN PEMBAHASAN}

Perkembangan

Tingkat

Pengangguran Terbuka Provinsi Sumatera Utara Tahun 2003-2017

Tingkat pengangguran terbuka

di Provinsi Sumatera Utara selama kurun waktu tahun 2003-2017 menunjukkan adanya penurunan. Hanya tingkat pengangguran terbuka pada tahun 2003 sebesar 7,71\% yang naik secara siginifikan menjadi 13,75\% pada tahun 2004. Sedangkan pada tahun-tahun berikutnya tingkat pengangguran terbuka menunjukkan penurunan secara umum menjadi 10,98\% pada tahun 2005 dan pada tahun 2017 sebesar 5,6\%.

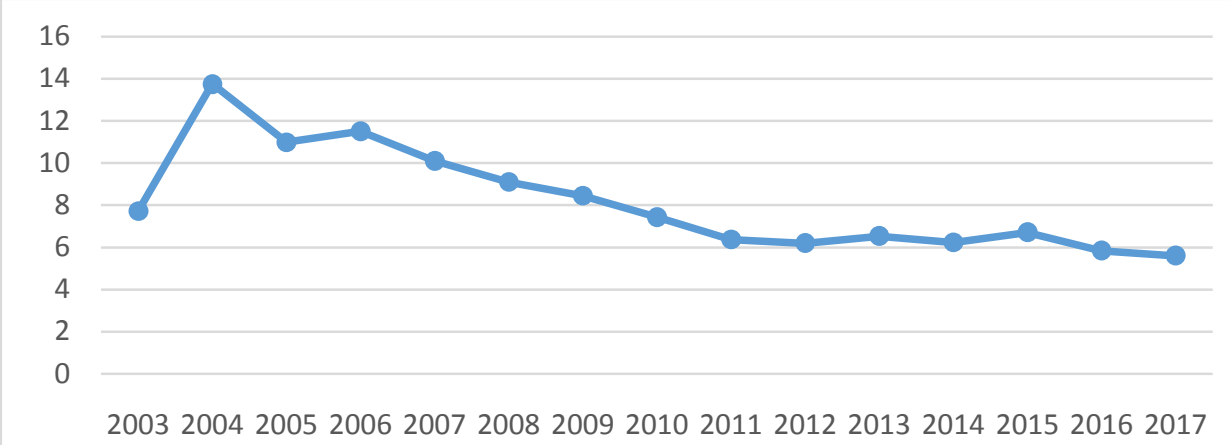

Gambar 1. Perkembangan Tingkat Pengangguran Terbuka Sumatera Utara Tahun 2003-2017 (\%) Sumber: Data diolah, 2019 
NUSANTARA : Jurnal Ilmu Pengetahuan Sosial - Vol. 6 No 1 (2019) ( Januari - Juni )

issn online : $2550-0813$ issn cetak : 2541-657X

http://jurnal.um-tapsel.ac.id/index.php/nusantara

Perkembangan Inflasi, Persentase
Penduduk Miskin, Upah Minimum
Regional dan Rata-rata Lama
Sekolah Provinsi Sumatera Utara
Tahun 2003-2017
Adapun perkembangan tingkat inflasi, persentase penduduk miskin, upah minimum regional dan rata-rata lama sekolah di Provinsi Sumatera Utara tahun 2003-2017 adalah sebagai berikut:

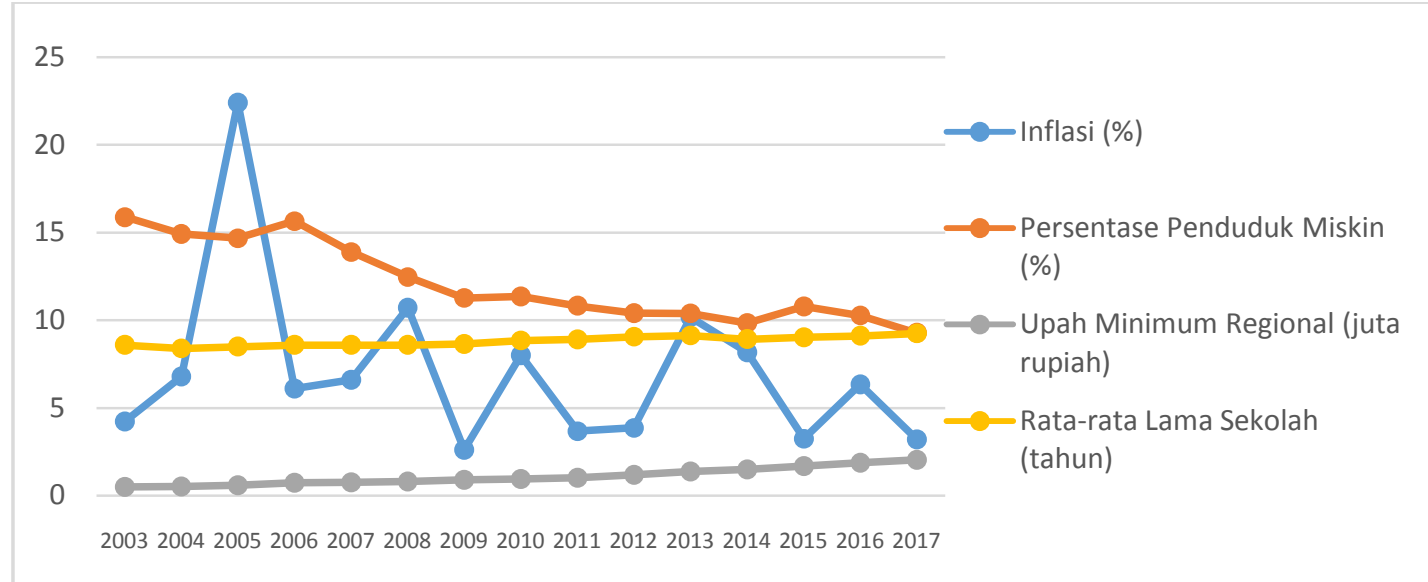

Gambar 2. Perkembangan Tingkat Inflasi, Persentase Penduduk Miskin, Upah Minimum Regional dan Rata-rata Lama SekolahSumatera Utara Tahun 2003-2017

Sumber: Data diolah, 2019

Berdasarkan gambar 2, dapat dilihat bahwa tingkat inflasi di Sumatera Utara tahun 2003-2017 mengalami fluktuasi, dimana tingkat inflasi terendah terjadi pada tahun 2009 sebesar 2,61\% sedangkan inflasi tertinggi terjadi pada tahun 2005 sebesar 22,41\% yang dikarenakan adanya kebijakan Presiden dalam melakukan 2 kali peningkatan harga premium. Sedangkan persentase penduduk miskin di Sumatera Utara tahun 2003-2017 mengalami penurunan secara umum, dimana persentase penduduk miskin pada tahun 2003 sebesar 15,89\% turun hingga $9,28 \%$ pada tahun 2017. Di sisi lain, upah minimum regional di Sumatera Utara tahun 2003-2017 justru mengalami kenaikan secara terus menerus, dimana upah minimum regional pada tahun 2003 sebesar
Rp.505.000,- naik hingga menjadi Rp. 2.039.000,- pada tahun 2017. Hal ini sejalan dengan rata-rata lama sekolah di Sumatera Utara tahun 2003-2017 yang juga mengalami peningkatan secara fluktuatif, dimana rata-rata lama sekolah paling rendah terjadi pada tahun 2004 yaitu sebesar 8,4 tahun. Sedangkan rata-rata lama sekolah tertinggi terjadi pada tahun 2017 yaitu sebesar 9,25 tahun.

\section{Uji Asumsi Klasik Uji Normalitas}

Hasil uji normalitas dapat dilihat pada tabel 1. Hasil pengujian normalitas dengan menggunakan Test Kolmogorov Smirnov menunjukkan data berdistribusi normal. Hal ini dibuktikan dengan nilai signifikansi yang nilainya lebih besar dari selang kepercayaan 5 persen.

\section{Tabel 1. One-Sample Kolmogorov-Smirnov Test}

\begin{tabular}{|l|lr|}
\hline Model & \multicolumn{2}{|c|}{ Hasil uji } \\
\hline $\mathrm{N}$ & & 15 \\
\hline
\end{tabular}


NUSANTARA : Jurnal Ilmu Pengetahuan Sosial - Vol. 6 No 1 (2019) ( Januari - Juni )

issn online : $2550-0813$ issn cetak : 2541-657X

http://jurnal.um-tapsel.ac.id/index.php/nusantara

Test Statistic

Asymp. Sig. (2-tailed)

0.141

Sumber: Data Diolah, 2019

\section{Uji Heterokesdasitas}

Hasil

pengujian

heterokesdasitas dengan Uji Glejser menunjukkan bahwa model regresi sudah baik karena tidak mengandung

heterokesdasitas dan layak digunakan dalam penelitian. Hal ini dibuktikan dengan nilai signifikansi semua variabel yang lebih besar dari selang kepercayaan 5 persen.

Tabel 2. Hasil Uji Heterokesdasitas dengan Uji Glejser

\begin{tabular}{|l|l|r|r|r|r|r|}
\hline \multicolumn{2}{|l|}{} & \multicolumn{2}{|c|}{$\begin{array}{c}\text { Unstandardized } \\
\text { Coefficients }\end{array}$} & $\begin{array}{c}\text { Standardized } \\
\text { Coefficients }\end{array}$ & & \\
\cline { 3 - 6 } \multicolumn{2}{|l|}{ Model } & \multicolumn{1}{|c|}{ B } & \multicolumn{1}{c|}{$\begin{array}{c}\text { Std. } \\
\text { Error }\end{array}$} & Beta & \multicolumn{1}{c|}{ t } & Sig. \\
\hline 1 & (Constant) & -9.729 & 16.351 & & -.595 & .565 \\
& Inflasi & -0.035 & 0.038 & -.253 & -.928 & .375 \\
& Persentase Penduduk & 0.249 & 0.160 & 0.821 & 1.549 & .152 \\
& Miskin & & & & & \\
& UMR (jutaan rupiah) & -0.098 & 0.908 & -0.071 & -0.108 & 0.916 \\
& Rata-rata Lama & 0.887 & 1.812 & 0.345 & 0.489 & 0.635 \\
Sekolah & & & & & \\
\hline
\end{tabular}

Sumber: Data Diolah, 2019

\section{Uji Autokorelasi}

Uji autokorelasi digunakan untuk melihat apakah ada korelasi variabel yang ada dalam model dengan perubahan waktu. Hasil pengujian Durbin Watson menunjukkan bahwa nilai Durbin Watson sebesar 2,448.
Nilai $\mathrm{d}_{\mathrm{u}}$ pada tabel 1,9774 dan nilai $\mathrm{d}_{\mathrm{L}}$ pada tabel 0,6852 sehingga bisa disimpulkan bahwa tidak ada autokorelasi karena $\mathrm{d}_{\mathrm{u}}<\mathrm{dw}$ dan (4$\mathrm{dw})>\mathrm{d}_{\mathrm{u}}$.

Tabel 3. Hasil pengujian Durbin Watson.

\begin{tabular}{|l|r|r|r|r|r|}
\hline Model & R & R Square & \multicolumn{1}{c|}{$\begin{array}{c}\text { Adjusted R } \\
\text { Square }\end{array}$} & $\begin{array}{c}\text { Std. Error of } \\
\text { the Estimate }\end{array}$ & Durbin-Watson \\
\hline 1 & $.906^{\mathrm{a}}$ & .820 & 0.748 & 1.22384 & 2.448 \\
\hline
\end{tabular}

Sumber: Data Diolah, 2019

\section{a. Uji Multikolineritas}

Uji Multikolineritas bertujuan untuk melihat apakah ada korelasi antar variabel bebas dalam model regresi. Model regresi yang baik harus bebas dari multikolineritas. Hasil uji multikolineritas dilihat dari nilai VIF atau Nilai Tolerance. Hasil Pengujian menunjukkan bahwa semua variabel tidak mengandung multikolineritas karena nilai VIF semua variabel lebih kecildari 10, sehingga model layak untuk digunakan dalam penelitian karena telah memenuhi asumsi. 
NUSANTARA : Jurnal Ilmu Pengetahuan Sosial - Vol. 6 No 1 (2019) ( Januari - Juni )

issn online : $2550-0813$ issn cetak : 2541-657X

http://jurnal.um-tapsel.ac.id/index.php/nusantara

Tabel 4. Hasil Uji Multikolineritas

\begin{tabular}{|ll|r|r|}
\hline \multirow{2}{*}{ Model } & \multicolumn{2}{|c|}{ Nilai Hasil Uji } \\
\cline { 3 - 4 } & & Tolerance & \multicolumn{1}{c|}{ VIF } \\
\hline \multicolumn{2}{|c|}{ (Constant) } & & \\
& & & \\
& Inflasi & 0.873 & 1.146 \\
& Persentase Penduduk Miskin & 0.232 & 4.313 \\
& UMR (jutaan rupiah) & 0.153 & 6.538 \\
& Rata-rata Lama Sekolah & 0.131 & 7.656 \\
\hline
\end{tabular}

Sumber: Data Diolah, 2019

Pengujian asumsi klasik

dilakukan untuk melihat apakah model

bersifat BLUE (Best linier unbias estimator). Hasil pengujian pada model regresi linier berganda menunjukkan bahwa model memenuhi asumsi normalitas, tidak mengandung heterokesdasitas, tidak terjadi

autokorelasi dan tidak terjadi multikolineritas.

\section{Analisis Regresi Linier Berganda}

Analisis regresi linier berganda bertujuan untuk melihat pengaruh antarainflasi, persentase penduduk miskin, upah minimum regional dan rata-rata lama sekolah terhadap tingkat pengangguran terbuka.

Tabel 5 Hasil Analisis Regresi Linier Berganda

\begin{tabular}{|l|r|r|r|r|}
\hline \multicolumn{1}{|c|}{ Variabel Bebas } & \multicolumn{1}{c|}{ Coefficient } & Standar Error & t-Statistik & Signifikansi \\
\hline Constant & 78,201 & 30,566 & 2,558 & 0,028 \\
\hline Inflasi & 0,32 & 0,71 & 0,446 & 0,665 \\
\hline Persentase Penduduk Miskin & 0,336 & 0,300 & 1,120 & 0,289 \\
\hline UMR (jutaan rupiah) & 1,949 & 1,697 & 1,149 & 0,277 \\
\hline Rata-rata Lama Sekolah & $-8,676$ & 3,387 & $-2,562$ & 0,028 \\
\hline R-squared & \multicolumn{5}{|l|}{} & 0,820 \\
\hline Adjusted R squared & \multicolumn{5}{|l|}{0,748} \\
\hline F-Statistik & \multicolumn{5}{|l|}{} & 11,413 \\
\hline Prob (F-statistik) & \multicolumn{5}{|l|}{0,001} \\
\hline
\end{tabular}

Sumber: Data Diolah,2019

Persamaan Regresi Linier Berganda

Persamaan Regresi linier berganda digambarkan sebagai berikut :

$\mathrm{Y}=78,201+0,32 \mathrm{X}_{1}+0,336 \mathrm{X}_{2}+$ $1,949 X_{3}-8,676 X_{4}+\varepsilon$

Nilai

konstanta

78,201menunjukkan bahwa nilai tingkat pengangguran terbuka di Provinsi Sumatera Utara sebesar 78,201 persen jika tidak ada pengaruh dari variabel inflasi, persentase penduduk miskin, upah minimum regional dan rata-rata lama sekolah. Persamaan di atas menunjukkan bahwa variabel inflasi, persentase penduduk miskin, upah minimum regional dan rata-rata lama sekolahmemberikan pengaruh yang berbeda terhadap tingkat pengangguran terbuka. Setiap kenaikan satu persen variabel inflasi akan menaikkantingkat pengangguran terbuka sebesar 0,32 persen. Kenaikan satu persen persentase penduduk miskin akan menaikkan tingkat pengangguran terbuka sebesar 0,336 persen. Kenaikan satu persen variabel upah minimum regional akan 
NUSANTARA : Jurnal Ilmu Pengetahuan Sosial - Vol. 6 No 1 (2019) ( Januari - Juni )

issn online : $2550-0813$ issn cetak : 2541-657X

http://jurnal.um-tapsel.ac.id/index.php/nusantara

memberikan kenaikan tingkat pengangguran terbuka sebesar 1,949 persen.Kenaikan satu persen rata-rata lama sekolah akan menurunkan tingkat pengangguran terbuka sebesar 8,676 persen. Hasil penelitian ini mendukung penelitian yang dilakukan oleh Suhendra dan Wicaksono (2016) dimana variabel inflasi dan upah memberikan pengaruh positif terhadap tingkat pengangguran terbuka.

\section{Uji Hipotesis}

\section{Koefisien Determinasi $\left(\mathbf{R}^{2}\right)$}

Hasil Perhitungan nilai $\mathrm{R}^{2}$ sebesar 0,820 artinya bahwa pengaruh variabel inflasi, persentase penduduk miskin, upah minimum regional dan rata-rata lama sekolahterhadap tingkat pengangguran terbuka sebesar 82 persen sedangkan 18 persen dipengaruhi oleh variabel lain di luar model.

\section{Uji Secara Simultan (Uji F)}

Hasil pengujian menunjukkan bahwa nilai $\mathrm{F}$ dihitung sebesar 11,413 dengan tingkat signifikansi sebesar 0,001 . Tingkat signifikansi $<0,05$ sehingga dapat disimpulkan bahwa tolak $\mathrm{H}_{0}$ dan terima $\mathrm{H}_{1}$ yang berarti bahwa secara bersama-sama (simultan) variabel inflasi, persentase penduduk miskin, upah minimum regional dan rata-rata lama sekolah berpengaruh positif terhadap tingkat pengangguran terbuka. Hasil uji $\mathrm{F}$ dapat dilihat pada tabel 5 .

\section{Uji Secara Partial (Uji t)}

Hasil pengujian menunjukkan bahwa secara partial bahwa dari keempat variabel bebas hanya variabel rata-rata lama sekolah yang berpengaruh terhadap tingkat pengangguran terbuka di Provinsi Sumatera Utara sedangkan variabel inflasi, persentase penduduk miskin, dan upah minimum regional tidak memberikan pengaruh terhadap tingkat pengangguran terbuka di Provinsi Sumatera Utara.

Variabel rata-rata lama sekolah berpengaruh secara nyata pada tingkat pengangguran terbuka di Provinsi Sumatera Utara dibuktikan dengan nilai signifikansi yang lebih kecil dari nilai signifikansi uji, nilai t-hitung dan signifikansi dapat dilihat pada tabel 5 . Rata-rata lama sekolah memberikan pengaruh nyata pada tingkat pengangguran terbuka karena melalui pendidikan yang diselesaikan seseorang diharapkan dapat melahirkan sumber daya manusia yang berkualitas. Pembinaan sumber daya manusia yang berkualitas adalah usaha memperbesar kemampuan produksi seseorang, baik dalam pekerjaan atau kegiatan lain yang dapat mempermudah orang tersebut ditempatkan dalam pekerjaan. Usaha pembinaan sumber daya manusia telah disetujui sebagai salah satu usaha penciptaan kesempatan kerja yang dapat mengurangi pengangguran (Suhendra \& Wicaksono, 2016). Hasil penelitian ini mendukung pendapat Wardiansyah \& Bahri (2016) yang menyatakan bahwa pendidikan memainkan kunci dalam membentuk kemampuan untuk menyerap teknologi modern dan untuk mengembangkan kapasitas seseorang. Pengaruh yang negatif dan signifikan faktor pendidikan terhadap tingkat penganggguran membuktikan bahwa semakin tinggi tingkat pendidikan yang diperoleh maka kemampuan untuk mengembangkan diri melalui kreatifitas dan inovasi akan semakin besar yang secara tidak langsung akan menurunkan tingkat pengangguran dengan terciptanya lapangan kerja baru.

\begin{tabular}{llr}
\multicolumn{2}{c}{ Variabel } & inflasitidak \\
berpengaruh & terhadap & tingkat \\
pengangguran & terbuka di & Provinsi
\end{tabular}


NUSANTARA : Jurnal IImu Pengetahuan Sosial - Vol. 6 No 1 (2019) (Januari - Juni )

issn online : $2550-0813$ issn cetak : $2541-657 \mathrm{X}$

http://jurnal.um-tapsel.ac.id/index.php/nusantara

Sumatera Utara karena nilai signifikansi lebih besar dari nilai signifikansi uji.Hasil pengujian secara partial dapat dilihat pada tabel 5. Hasil penelitian ini bertentangan dengan penelitian yang dilakukan oleh Suhendra dan Wicaksono (2016) yang menunjukkan bahwa variabel inflasi dan upah berpengaruh terhadap tingkat pengangguran terbuka. Secara teori inflasi mempengaruhi tingkat pengangguran. Tingkat pengangguran akan bertambah seiring dengan kenaikan tingkat inflasi, hal ini diakibatkan oleh rendahnya investasi karena inflasi yang terjadi yang meningkatkan naiknya tingkat bunga pinjaman usaha (Ramdhan et al., 2017). Inflasi berpengaruh positif dan tidak signifikan terhadap tingkat pengangguran di Provinsi Sumatera Utara karena inflasi cenderung stabil dan masih terkendali sehingga tidak berdampak pada investasi dan pada usaha ekonomi baru.

Variabel persentase penduduk miskin tidak berpengaruh terhadap tingkat pengangguran terbuka di Provinsi Sumatera Utara karena nilai signifikansi lebih besar dari nilai signifikansi uji. Hasil pengujian secara partial dapat dilihat pada tabel 5 . Kemiskinan dan pengangguran mempunyai hubungan yang erat yaitu pengangguran akan meningkatkan kemiskinan apabila ditinjau dari segi ekonomi. Karena banyaknya pengangguran akan berdampak pada rendahnya pendapatan ekonomi mereka, sementara biaya hidup terus berjalan. Hal ini akan membuat mereka tidak dapat mandiri dalam menghasilkan finansial untuk kebutuhan hidup para pengangguran (Franita, 2016). Namun ternyata melalui penelitian ini, teori tersebut tidak berlaku sebaliknya. Karena meskipun mempunyai pengaruh positif namun variabel persentase jumlah penduduk miskin ternyata tidak signifikan dalam mempengaruhi tingkat penggangguran di Provinsi Sumatera Utara.

Variabel upah minimum regional tidak berpengaruh terhadap tingkat pengangguran terbuka di Provinsi Sumatera Utara karena nilai signifikansi lebih besar dari nilai signifikansi uji. Hasil pengujian secara partial dapat dilihat pada tabel 5 . Besaran upah minimum regional yang ditetapkan di Provinsi Sumatera Utara ternyata memiliki peranan dalam rangka mengurangi angka pengangguran. Dimana peningkatan upah minimum regional berkorelasi positif terhadap tingkat pengangguran karena semakin tinggi upah maka semakin sedikit permintaan terhadap tenaga kerja yang berarti semakin banyak pengangguran (Ramdhan et al., 2017). Namun variabel upah minimum regional ternyata tidak siginifikan dalam mempengaruhi tingkat pengangguran terbuka di Provinsi Sumatera Utara yang disebabkan olehpesatnya peningkatan teknologi yang menggantikan tenaga manusia. Hal ini berpengaruh terhadap kurangnya permintaan tenaga kerja tanpa harus diikuti dengan kenaikan upah.

\section{KESIMPULAN}

Berdasarkan hasil penelitian yang telah dilakukan maka dapat disimpulkan bahwa model persamaan regresi berganda layak dilanjutkan karena telah memenuhi uji asumsi klasik yaitu uji normalitas, uji heterokesdasitas, uji autokoreksi dan uji multikolineritas. Hasil analisis regresi berganda menunjukkan bahwa pengaruh variabel inflasi, persentase penduduk miskin, upah minimum regional dan rata-rata lama sekolah terhadap tingkat pengangguran 
NUSANTARA : Jurnal Ilmu Pengetahuan Sosial - Vol. 6 No 1 (2019) ( Januari - Juni )

issn online : $2550-0813$ issn cetak : 2541-657X

http://jurnal.um-tapsel.ac.id/index.php/nusantara

terbuka sebesar 82 persen sedangkan 18 persen dipengaruhi oleh variabel lain di luar model. Secara simultanvariabel inflasi, persentase penduduk miskin, upah minimum regional dan rata-rata lama sekolah berpengaruh positif terhadap tingkat pengangguran terbuka, namun secara partial dari empat variabel bebas hanya variabel rata-rata lama sekolah yang berpengaruh terhadap tingkat pengangguran terbukasedangkan variabel inflasi, persentase penduduk miskin, dan upah minimum regional tidak memberikan pengaruh terhadap tingkat pengangguran terbuka di Provinsi Sumatera Utara.

\section{DAFTAR PUSTAKA}

Bangun, R. H. (2018). Determinan Produksi Ikan Tangkap Di Kota Sibolga. Jurnal Agrica, 11(1), 28-38.

BPS. (2018a). Keadaan Angkatan Kerja di Provinsi Sumatera Utara Februari 2018. Medan: BPS Provinsi Sumatera Utara.

BPS. (2018b). Statistik Indonesia 2018. Jakarta: Badan Pusat Statistik.

Firdhania, R., \& Muslihatinningsih, F. (2017). Faktor-Faktor yang Mempengaruhi Tingkat Pengangguran di Kabupaten Jember. Jurnal Ekonomi Bisnis Dan Akutansi, IV(1), 117-121

Franita, R. (2016). Analisa Pengangguran Di Indonesia. Jurnal Ilmu Pengetahuan Sosial,
1, 88-93.

Muslim, M. R. (2014). Pengangguran Terbuka Dan Determinannya. Jurnal Ekonomi Dan Studi Pembangunan Volume 15, Nomor 2, 15(2), 171-181.

Ramdhan, D. A., Setyadi, D., \& Wijaya, A. (2017). Faktor-Faktor Yang Mempengaruhi Tingkat Pengangguran Dan Kemiskinan Di Kota Samarinda. Jurnal Inovasi, 13(1), 1-18.

Sidania, J., Wibisono, S., \& S, R. P. (2017). Determinan Tingkat Pengangguran Terbuka di Provinsi Banten Tahun 20082013. Jurnal Ekonomi Bisnis Dan Akutansi, IV(2), 169-172.

Suhendra, B., \& Wicaksono, B. H. (2016). Tingkat Pendidikan, Upah, Inflasi, Dan Pertumbuhan Ekonomi Terhadap Pengangguran Di Indonesia. Jurnal Ekonomi Pembangunan, 6(1), 1-17.

Susanto, E., Rochaida, E., \& Ulfah, Y. (2017). Pengaruh Inflasi Dan Pendidikan Terhadap Pengangguran Dan Kemiskinan. Jurnal Inovasi, 13(1), 19-27

Wardiansyah, M., \& Bahri, Z. (2016). Analisis Faktor-Faktor Yang Mempengaruhi Tingkat Pengangguran ( Studi Kasus Provinsi-Provinsi Se-Sumatera ). Jurnal Ekonomi Sumberdaya Dan Lingkungan, 5(1), 13-18. 